Arcybiskup A. Bugnini CM, który był sekretarzem Komisji przygotowującej Konstytucję o liturgii oraz sekretarzem Rady do wykonania Konstytucji o liturgii, zaliczył o. Vagagginiego do grupy „nieznanych żołnierzy” dzieła odnowy liturgii. Ich wyrzeczenie się osobistych sukcesów w nauce i ofiarna praca nad projektami konstytucji oraz nowych ksiąg liturgicznych sprowadziły błogosławieństwo Boże na dzieło reformy. Chociaż ich nazwiska nie widnieją w księgach liturgicznych, możemy ufać, że zostały zapisane w niebie.

Tyniec

O. FRANCISZEK MAEACZYŃSKI OSB

\title{
Z KRONIKI ŻAŁOBNEJ
}

\section{SCHALOM BEN CHORIN (1913-1999)}

W maju br. zmarł w Jerozolimie Schalom Ben Chorin, dziennikarz i pisarz, który w sposób szczególny zajmowal się problematyką biblijną i dialogiem chrześcijańsko-żydowskim.

Urodzony w Monachium w 1913 roku, osiedlił się w roku 1935 w Jerozolimie, zmieniając swoje niemieckie nazwisko Fritz Rosenthal na hebrajskie Schalom Ben Chorin (tzn. Pokój Syn Wolności).

Wśród wielu jego książek i artykułów najbardziej znane są książki: Bruder Jesus, der Nazarener in jüdischer Sicht (1970), Paulus, der Völkerapostel in jüdischer Sicht (1970), Mutter Mirjam, Maria in jüdischer Sicht (1971).

\section{HELMUT MERKLEIN (1940-1999)}

Z początkiem października br. zmarł Helmut Merklein, profesor egzegezy Nowego Testamentu w Uniwersytecie Bonn i przewodniczący Katholisches Bibelwerk w Stuttgarcie.

Urodzony w 1940 roku w Aub k. Würzburga, pracował jako asystent Rudolfa Schnackenburga w Würzburgu, od 1976 r. w Wuppertalu, a od 1980 w Bonn. Od roku 1992 pełnił funkcję przewodniczącego Katolickiego Dzieła Biblijnego. Był jednym z założycieli w roku 1996 czasopisma „Welt und Umwelt der Bibel”. 